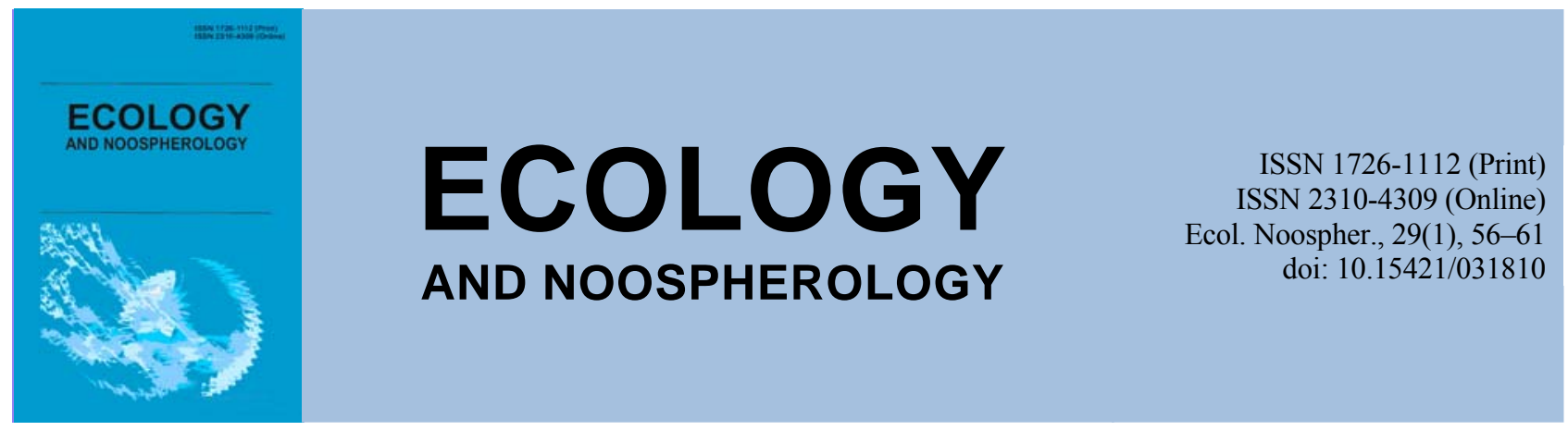

\title{
Features of herpetofauna dynamics in the Nature Reserve «Dniprovsko-Orilsky» under conditions of climate change
}

\author{
V. Ya. Gasso*, S. V. Yermolenko*, V. M. Kochet**, A. M. Hagut*, O. Ye. Pakhomov* \\ * Oles Honchar Dnipro National University, Dnipro, Ukraine \\ ** Nature Reserve «Dniprovsko-Orilsky», Dnipropetrovsk region, Ukraine
}

Article info

Received 15.05.2018

Received in revised form 21.05.2018

Accepted 27.05.2018

Oles Honchar Dnipro

National University,

Gagarin Ave., 72, Dnipro,

49010, Ukraine.

Tel.: +38-095-574-61-51

E-mail:vgasso@ua.fm

Nature Reserve «Dniprovsko-

Orilsky», Obukhivka,

Dnipropetrovsk region,

52030, Ukraine.
Gasso, V. Ya., Yermolenko, S. V., Kochet, V. M., Hagut, A. M., \& Pakhomov, O. Ye. Features of herpetofauna dynamics in the Nature Reserve "Dniprovsko-Orilsky" under conditions of climate change. Ecology and Noospherology, 29(1), 56-61. doi:10.15421/031810

The Nature Reserve «Dniprovsky-Orilsky» occupies unique ecosystems of the floodplain of the middle part of the Dnieper River, where the medium-flooded forests (black poplar and willow forests, elm-Tatarian maple oakeries, and pine forests at the sandy second terrace) predominate. Marshy, wet and dry meadows, sandy steppes, salt marshes, floodplain lakes and isles support the diversity of habitats. Reptiles, like ectothermic organisms, are known to be sensitive to temperature and humidity, which are directly influenced by climate change. Due to the variety of species and their habitats' conditions, it is important to study the possible effects of climate change on each species and each place of their residence separately. Studies in more or less natural conditions of the Reserve allow minimizing the impact of the anthropogenic factors on the number and diversity of species. To produce accurate inventories we use the method of linear transects created at survey sites modified by Dinesman and Kaletskaya (1952) with a width of transects up to 3 meters. The length of the survey route depended on the availability for an accountant, but was not less than $1.0 \mathrm{~km}$ in all cases. The surveys were conducted during the period of maximum daily activity of reptiles in the spring-summer period on specified routes. The density of reptiles was described as the number of individuals per hectare of an averaged ecosystem. In aquatic and wetland ecosystems, the population density of European pond turtle and dice snake were determined as a number of specimens per $1 \mathrm{~km}$ of the waterbody's bankline. During almost 30 years of observation, eight reptile species have been registered on the territory of the Dniprovsky-Orilsky Nature Reserve, among which three species (Coronella austriaca, Natrix tessellata and Dolichophis caspius) have been recorded in the last decade. In recent years (since 1972), the average increase in the temperature of the surface air layer in Ukraine was more than $1^{\circ} \mathrm{C}$. In winter, in the central regions of the country, the highest increase in the average monthly air temperature is observed. The excess reaches $2{ }^{\circ} \mathrm{C}$ and more. Climatic changes can be the reason for the invasion and the number growth of the dice snake and the appearance of the Caspian whipsnake within the Reserve. In the context of general climate change, there is a tendency to reduce the population density of the pond turtle, sand lizard and grass snake. At the same time, there is a gradual increase in the number of steppe vipers. Preserving current temperature trends in the coming years can create favourable conditions for another reptile species - the blotched snake (Elaphe sauromates) - to penetrate into the Reserve, but also negatively affect the hygrophilic species. Increasing the risk of summer fires in the Nature Reserve «Dniprovsky-Orilsky» is one of the most threatening factors for the conservation of the terrestrial biota, including reptiles.

Keywords: reptiles, species diversity, population density, population dynamics, warming

\section{Особливості динаміки герпетофауни природного заповідника «Дніпровсько-Орільський» в умовах кліматичних змін}

\author{
В. Я. Гассо*, С. В. Срмоленко*, В. М. Кочет**, А. М. Гагут*, О. Є. Пахомов*
}


За майже 30 років спостережень на території природного заповідника «Дніпровсько-Орільський» зареєстровано вісім видів плазунів, серед яких три види (Coronella austriaca, Natrix tessellata та Dolichophis caspius) зафіксовані в останнє десятиріччя. Відомо, що плазуни, як ектотермні організми, чутливі до режиму температур та вологості, на які безпосередньо впливають зміни клімату. За останні роки (з 1972 р.) середнє підвищення температури приземного шару повітря в Україні склало більше $1{ }^{\circ} \mathrm{C}$. Взимку в центральних районах країни відзначається найбільше підвищення середньомісячної температури повітря, яке досягає $2{ }^{\circ} \mathrm{C}$ і більше. Кліматичні зміни можуть бути причиною появи і росту чисельності у межах заповідника водяного вужа та появи каспійського полоза. На фоні загальних змін клімату спостерігається певна тенденція щодо зменшення щільності населення болотної черепахи, прудкої ящірки та звичайного вужа. У той же час зберігається поступовий ріст чисельності степової гадюки. Збереження температурних трендів у найближчі роки може створити сприятливі умови для проникнення на територію заповідника ще одного виду рептилій - сарматського полоза, але негативно впливати на гігрофільні види. Підвищення ризику пожеж у літні місяці стає одним 3 найбільш загрозливих факторів для збереження наземної біоти, у тому числі й плазунів, природного заповідника «Дніпровсько-Орільський».

\section{Ключові слова: плазуни, видове розмаїття, щільність населення, динаміка чисельності, потепління}

\section{Вступ}

Природний заповідник «Дніпровсько-Орільський» займає унікальні екосистеми заплави середньої течії p. Дніпро, де переважають середньозаплавні ліси (осокірники, біловербняки, в'язово-чорнокленові діброви, соснові бори на арені). Різноманіття біотопів підтримується заболоченими, вологими та сухими луками, піщаним степом, солончаками, заплавними озерами та островами.

Заповідник налічує понад 800 видів рослин та лишайників, понад 2000 видів тварин. Результати наших досліджень підтверджують наявність восьми видів плазунів у фауні заповідника. Рептилії вважаються однією 3 найвразливіших груп наземних хребетних, які $\epsilon$ чутливими до антропогенних впливів різного характеру та до кліматичних змін.

Відомо, що плазуни, як ектотермні організми, чутливі до режиму температур та вологості, на які безпосередньо впливають зміни клімату. Через різноманітність видів та умов їх існування важливо дослідити можливі наслідки змін клімату на кожний вид та кожне місце їх проживання окремо (Olson, 2013). Дослідження у більш-менш природних умовах заповідника дозволяють звести до мінімуму вплив саме антропогенної діяльності на чисельність та різноманіття видів.

У помірних широтах вихід 3 зимівлі, період розмноження, тривалість сезону активності та початок гібернації плазунів залежить, у першу чергу, від температурних режимів. Розмноження рептилій відбувається у вузький період часу навесні, коли існують критичні для живлення та спарювання відповідні режими температури та вологості.

Більш вразливими до змін клімату вважаються ящірки (Araujo et al., 2006; Sinervo et al., 2010; Moreno-Rueda et al., 2011; Zani, Rollyson, 2011). Але останні дослідження моделей кліматичних ніш змій вказують на зменшення сприятливих умов для денних видів (Lawing, Polly, 2011), у той час як сутінкові види збільшили активність через більш теплі нічні температури (Weatherhead et al., 2012).

Більшість черепах, у тому числі й болотна черепаха, мають температурно залежне формування статі на стадії ембріону. Більш прохолодна температура може спричинити появу лише самців, підвищені температури спричиняють формування самиць. Зміни температури на регіональному (та навіть локальному) рівні можуть мати вплив на співвідношення статей в популяціях, що потенційно впливає на майбутні цикли розмноження і 3 часом можуть ускладнювати еволюційну пристосованість цих популяцій (Gibbons et al., 2000). Температурні умови впливають також на характеристики місць кладок яєць у плазунів (Refsnider, 2012).

За останні роки (3 1972 р.) середнє підвищення температури приземного шару повітря в Україні склало більше $1^{\circ} \mathrm{C}$. Взимку в центральних районах країни відзначається найбільше підвищення середньомісячної температури повітря, яке досягає $2^{\circ} \mathrm{C}$ і більше (Shurda, 2014). Потепління в Україні характеризується зниженням континентальності клімату, появою на тлі загального потепління хвиль холоду із заморозками, що навесні представляє серйозну небезпеку для плазунів, які можуть завчасно виходити 3 гібернації. 3 іншого боку, хвилі значного потепління взимку можуть призводити до пробудження плазунів вдень, але з високою вірогідністю їх загибелі вночі. Такий випадок появи степової гадюки зафіксований 30 грудня 2017 року на околиці м. Новомосковська. Важливою особливістю сучасного клімату України стали також різкі перепади добових температур повітря в межах $10-15^{\circ} \mathrm{C}$ протягом $1-2$ діб. Такі перепади неодмінно впливають на характеристики наявних теплових ніш для ектотермних організмів, звужуючі при похолоданні проміжок часу добової активності.

\section{Матеріали та методи досліджень}

Адміністративно природний заповідник «ДніпровськоОрільський» знаходиться у межах Дніпропетровській області, Дніпропетровського та Петриківського районів. Він розташований на лівобережжі р. Дніпро та включає плавні сучасного русла р. Оріль. Заповідник створений у 1990 році на базі загальнозоологічного та орнітологічного заказників «Таромський уступ» та «Обухівські плавні» загальною площею 3766 га. Водна межа заповідника проходить акваторією Дніпровського водосховища від гирла р. Оріль до Таромського і Миколаївського уступів, включає острови Кам'янистий, Крячиний i частково Корчуватий (рис. 1).

Вивчення герпетофауни майбутнього заповідника проводили ще до його адміністративного заснування, 3 початку 1980-х років. Перші дослідження стосувалися екології та біохімії озерної жаби порівняно 3 хімічно забрудненими екосистемами (Misyura, 1981, 1984). 3 часом герпетологічні дослідження у заповіднику охоплювали все більше видів та екосистем (Misyura et al., 1992; Gasso, Suhanova, 1993; Gasso, 1998, 1999). Починаючи з 2012 року уперше згідно діючих методик та вимог до Літопису природи було укладено систему 3 10-ти облікових маршрутів для дослідження плазунів. 32014 року таких маршрутів стає вже 11. Для вивчення стану герпетофауни щорічно проводили до 35 маршрутних обліків, які охоплювали основні типи аренних, лучних, острівних та водних біогеоценозів заповідника.

Дослідження проводилися методом лінійних облікових смуг в модифікації Dinesman та Kaletskaya (1952) 3 шириною трансекти до 3 метрів. Довжина маршруту обумовлена доступністю і у всіх випадках складала не 


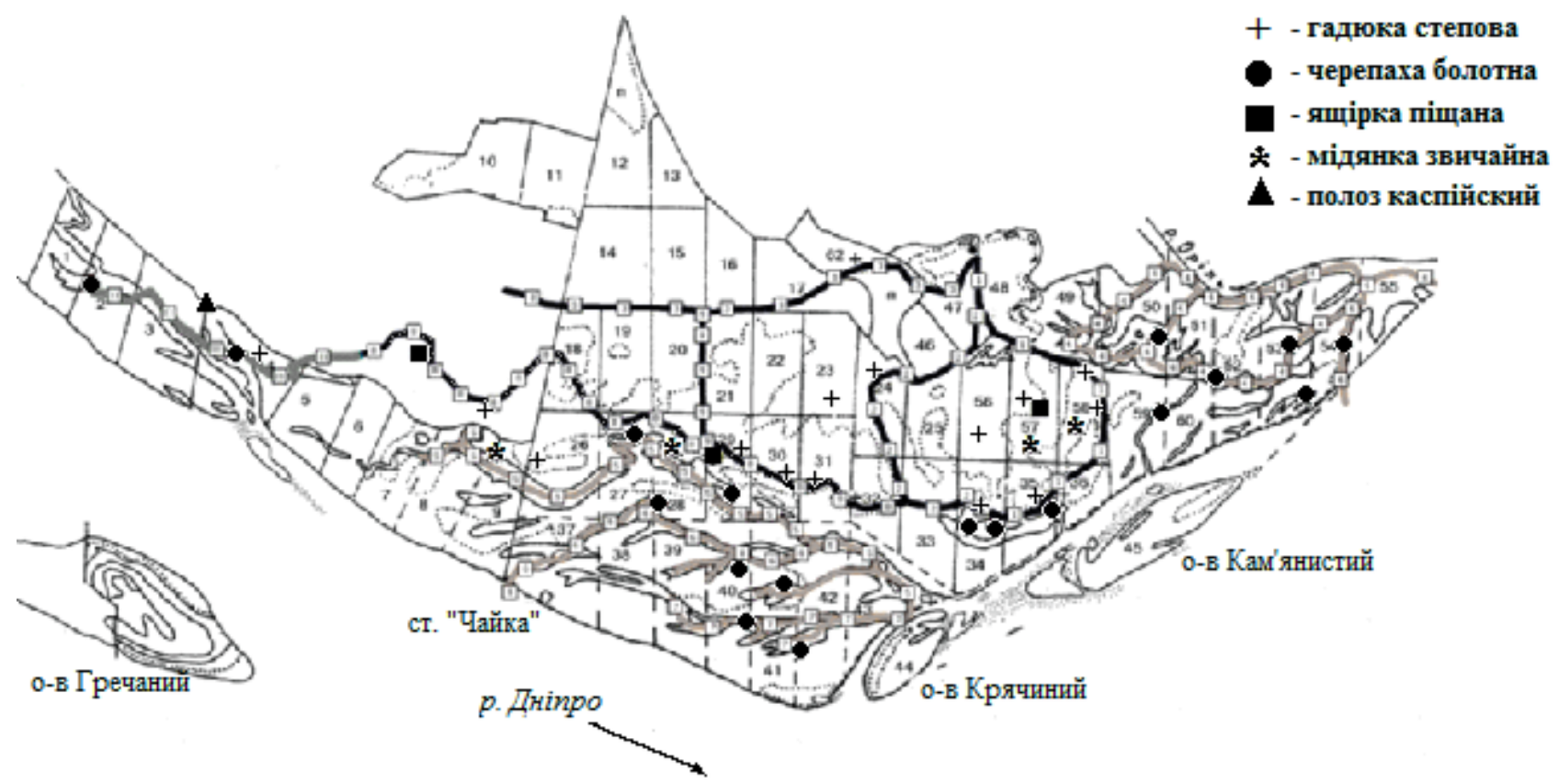

Рис. 1. Карта-схема маршрутів обліку та основні точки знахідок герпетофауни природного заповідника «Дніпровсько-Орільський»

менше 1,0 км. Обліки проводилися у період максимальної добової активності плазунів у весняно-літній період на лінійних облікових смугах по визначених маршрутах.

Щільність плазунів встановлювали як кількість особин на гектар усередненої екосистеми. У водних i навколоводних екосистемах щільність населення болотної черепахи та водяного вужа визначали у кількості екземплярів на 1 км берегової смуги.

\section{Результати та їх обговорення}

Багаторічними дослідженнями у складі герпетофауни заповідника зафіксовано 8 видів рептилій:

1. Черепаха болотна - Emys orbicularis (Linnaeus, 1758).

2. Ящірка прудка - Lacerta agilis (Linnaeus, 1758).

3. Ящірка піщана - Eremias arguta (Pallas, 1773).

4. Вуж звичайний - Natrix natrix (Linnaeus, 1758).

5. Вуж водяний - Natrix tessellata (Laurenti, 1768).

6. Мідянка звичайна - Coronella austriaca (Laurenti, 1768).

7. Гадюка степова - Vipera renardi (Christoph, 1861).

8. Полоз каспійський - Dolichophis caspius (Gmelin, 1789).

3 них три види - гадюка степова, мідянка звичайна та полоз каспійський - занесені до Червоної Книги України (2009), а ящірка піщана та черепаха болотна є рідкісними видами Дніпропетровської області (Pakhomov et al., 2011).

Таким чином, герпетофауна заповідника складає майже $67 \%$ сучасного видового різноманіття рептилій фауни Дніпропетровської області та приблизно $36 \%$ плазунів України. 3 моменту заснування заповідника фауна плазунів зазнала певних змін, які проявилися не тільки у динаміці чисельності видів, але й у видовому складі рептилій. У перші роки запровадження заповідного режиму видовий склад герпетофауни налічував шість видів, а їх чисельність почала збільшуватися порівняно 3 періодом до заповідання (Misyura et al., 1992).

У липні 2008 року в межах заповідника вперше був зафіксований водяний вуж. У наступні чотири роки відомі лише поодинокі знахідки. 32013 року зустрічі водяного вужа стають регулярними, хоча його чисельність залишається невисокою - не більше 5 особин на кілометр маршруту на ділянках у острова Кам'янистий (рис. 2). Цьоголіток водяних вужів на території заповідника поки не знайдено.
Мідянку звичайну знайдено у 2014 р. на піщаних кучугурах в районі озера Солоне. У наступні роки знаходили одиничні екземпляри, тому об'єктивно оцінити щільність виду на даний момент складно. У той же час низька щільність популяції характерна для цього виду і не свідчить про загрозливість стану популяції, але обов'язково потребує спеціальних досліджень.

Також у 2014 році у межах заповідника у степових біотопах, що межують 3 ділянкою Миколаївського уступу, вперше за більш ніж 50 років зареєстрований полоз каспійський. Оскільки поки знайдено лише 1 екземпляр, визначити характер перебування виду у заповіднику на теперішній час не можливо.

Таким чином, за час спостережень видовий склад герпетофауни заповідника збільшився на три види, якщо вдасться засвідчити проживання каспійського полоза на території. Географічно маємо просування у нашому регіоні на північ двох південних видів - водяного вужа (підтверджено) та каспійського полоза (потребує додаткового підтвердження). 3 точки зору відомих кліматичних змін таке просування виникає цілком закономірним.

Поступово наближається до меж заповідника сарматський полоз (Elaphe sauromates (Pallas, [1814])). В останні роки почастішали його знахідки на лівобережжі, навіть у межах м. Дніпро.

Про «південне» розповсюдження водяного вужа в цілому свідчить його ареал в цілому та розповсюдження в Україні (Kurtyak et al., 2012; Smirnov, Skilsky, 2017; The Reptile Database, 2018). У той же час, є літературні дані про мешкання водяного вужа i північніше: у Харківській, Полтавській, Київський та Черкаській областях (Nekrasova et al., 2013; Zinenko et al., 2014). Загальне розповсюдження водяного вужа в цілому відповідає, за деякими виключеннями, 50-ї паралелі (Kotenko et al., 2011). У межах Дніпропетровської області в долині р. Дніпро до 2007 року водяний вуж зустрічався тільки південніше м. Дніпра, нижче за течією. Його просування на північ в умовах регіону вочевидь пов'язане зі збільшенням чисельності виду та наявністю достатньої кормової бази у першу чергу бичків (Gobiidae) (Khobot et al., 2014). У подальшому зі змінами кліматичних умов прогнозується подальше просування цього виду на північ (Nekrasova, Tytar, 2014). 


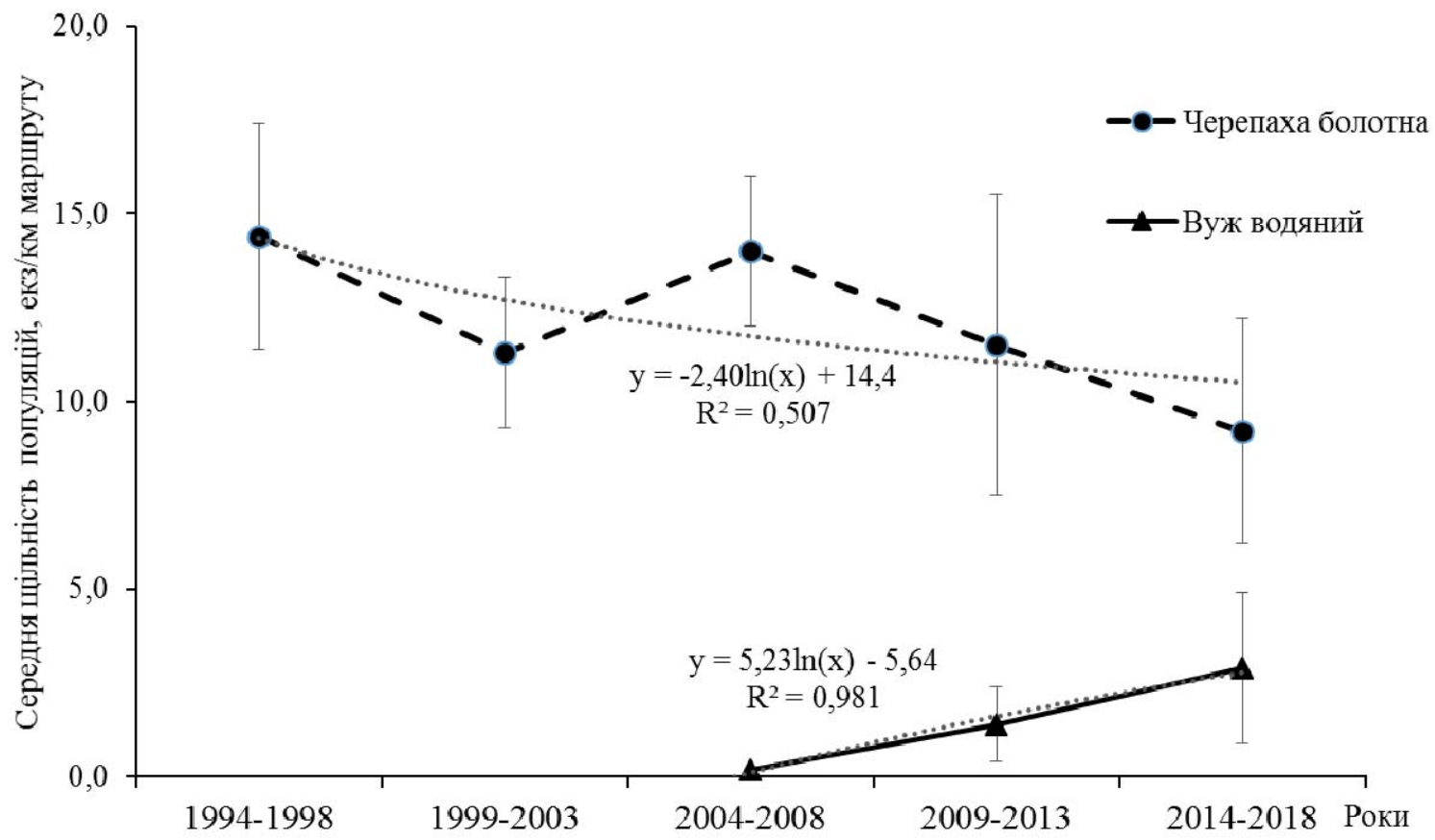

Рис. 2. Динаміка щільності населення болотної черепахи та водяного вужа у водних екосистемах природного заповідника «Дніпровсько-Орільський»

Аналіз динаміки чисельності плазунів за останні 30 років спостережень вказують на загальну тенденцію зниження щільності населення популяцій трьох видів плазунів. Така тенденція спостерігається для болотної черепахи (рис. 2), прудкої ящірки та звичайного вужа (рис. 3).
За період спостережень умови існування на території заповідника змінювалися таким чином, що багато тимчасових весняних водойм, які ще на наприкінці 1990-х та початку 2000-х рр. зберігалися до кінця квітня середини травня, вже у 2010-х рр. висихали на 1-3 тижні

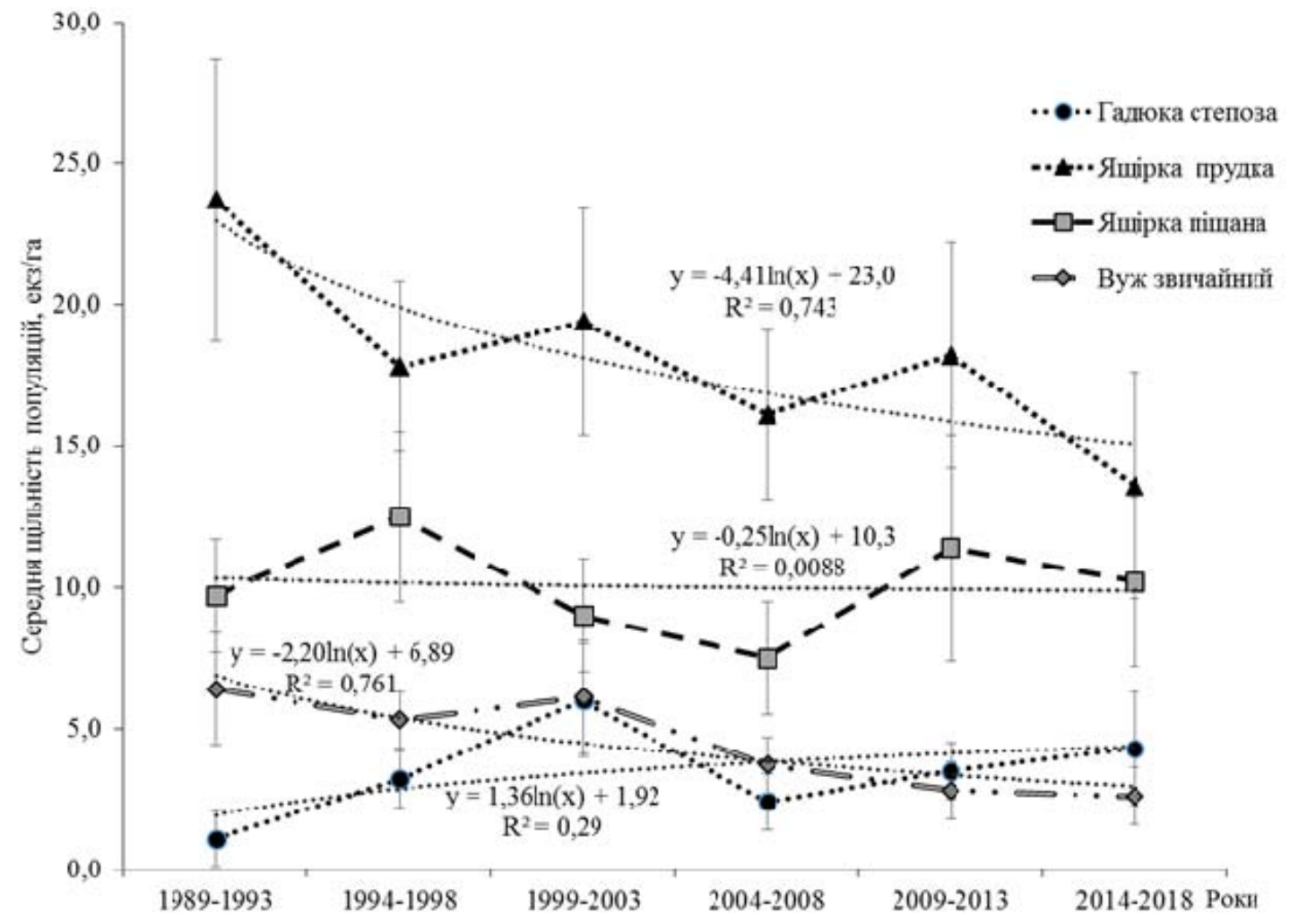

Рис. 3. Динаміка щільності населення плазунів у наземних екосистемах природного заповідника «Дніпровсько-Орільський»

раніше. Відповідно багато ділянок, які зберігалися вологими до початку літа, стали сухими, що впливає на розповсюдження земноводних (як об'єктів живлення) та обмежує територію добових міграцій звичайного вужа. За нашими спостереженнями в останні роки звичайні вужі зустрічаються влітку лише у водних біотопах та на вологих луках.

Для черепахи одним 3 лімітуючих факторів на території заповідника $\epsilon$ наявність ділянок суходолу, придатних для інкубації яєць. Кліматичні зміни впливають на глибину, швидкість та величину прогрівання грунту, що 
може позначатися на успішності інкубації. Такі самі фактори можуть впливати і на інкубацію яєць прудкої ящірки. При цьому їх вразливість більша через іншу структуру зовнішніх оболонок яйця, яке відносно швидше втрачає вологу в умовах сухого оточення. Вплив кліматичних змін позначився на просторовому розподілі популяцій прудкої ящірки. Ящірки в популяції майже в 1,5 рази менше часу на добу проводять на відкритих ділянках зі степовою рослинністю, а більше під кронами дерев та біля води відносно наших спостережень у 1990-ті роки. Збільшився i період спокою під час літніх добових піків температур. До того ж і щільність населення прудкої ящірки в лучних екосистемах стала вищою або порівнянною 3 аренними біотопами, на відміну від ситуації 20-ти річної давнини.

Ящірка піщана хоч і не демонструє в цілому зниження щільності населення популяцій, але загальна їі чисельність та кількість популяцій (всього три) зберігаються низькими. На території заповідника цей вид мешкає на ділянках відкритих незакріплених пісків. Отже зі змінами клімату та термічних характеристик пісків популяції піщаної ящірки можуть опинитися під загрозою.

У той же час відносне підвищення чисельності на території заповідника демонструє степова гадюка (рис. 3). Це може свідчити про сприятливі температурні, біотопічні та кормові характеристики екологічної ніші цього виду у межах заповідника.

Слід зазначити, що на динаміку чисельності плазунів вплинули лісові пожежі 1998 та 2005 років. Вважається, що збільшення температур, яке супроводжує сучасні зміни клімату, підвищує ризики виникнення та збільшення масштабів пожеж у лісових та степових екосистемах (Balabuh, Zibtsev, 2016). Такі умови підвищують рівень небезпеки для флори і фауни заповідника, у тому числі й для більшості видів плазунів.

\section{Висновки}

На території природного заповідника «ДніпровськоОрільський» зареєстровано вісім видів плазунів, серед яких три види зафіксовані в останнє десятиріччя. Кліматичні зміни можуть бути причиною появи i росту чисельності у межах заповідника водяного вужа та появи каспійського полоза. На фоні загальних змін клімату відстежується певна тенденція щодо зменшення щільності населення болотної черепахи, прудкої ящірки та звичайного вужа. У той же час зберігається поступовий ріст чисельності степової гадюки. Збереження температурних трендів у найближчі роки може створити сприятливі умови для проникнення на територію заповідника ще одного виду рептилій - сарматського полоза, але негативно впливати на гігрофільні види. Підвищення ризику пожеж у літні місяці стає одним 3 найбільш загрозливих факторів для збереження наземної біоти, у тому числі й плазунів, природного заповідника «Дніпровсько-Орільський».

\section{References}

Araujo, M. B., Thuiller, W., Pearson, R. G. (2006). Climate warming and the decline of amphibians and reptiles in Europe. Journal of Biogeography, 33, 1712-1728.

Balabuh, V. O., Zibtsev S. V. (2016). Vplyv zminy klimatu na kilkist ta ploschu lisovyh pozhezh $u$ pivnichnochornomorskomu regioni Ukraini [Impact of climate change on the number and area of forest fires in the North Black Sea region of Ukraine]. Ukrainskyj hidrometeorologichnyj zhurnal, 18, 60-71 (in Ukrainian).

Bulakhov, V. L., Gasso, V. Ya., Pakhomov, O. Ye. (2007). Biologichne riznomanittya Ukrainy. Dnipropetrovs'ka oblast'. Zemnovodni ta plazuny (Amphibia et Reptilia) [Biological Diversity of Ukraine. The Dnipropetrovsk region. Amphibians and Reptiles (Amphibia et Reptilia)]. Dnipropetr. Nat. Univ. Press, Dnipropetrovsk (in Ukrainian).

Chervona knyga Ukrainy. Tvarynnyi svit. (2009). [Red Data Book of Ukraine. Animal World]. Za red. A. I. Akimova. Globalkonsalting, Kyiv (in Ukrainian).

Dinesman, L. G., Kaletskaya, M. L. (1952). Metody kolichestvennogo ucheta amfibiy i reptiliy. [Methods for quantitative accounting of amphibians and reptiles]. Metody ucheta chislennosti i geograficheskogo raspredeleniya nazemnyh pozvonochnyh. AN SSSR, Moscow, 329-341 (in Russian).

Gasso, V. Ya. (1998). Ispolzovanie massovyh vidov presmykayuschihsya dlya biomonitoringa sostoyaniya okruzhayushej sredy $\mathrm{v}$ zapovednikah [The use of numerous reptile species for biomonitoring of the environment in nature reserves]. Aktualni pytannya zberezhennya ta vidnovlennya stepovyh ekosystem. Mater. mizhnar. nauk. konfer., prisvyach. 100-richchyu zapovidannya askanijskogo stepu. AskaniyaNova, 255-257 (in Russian).

Gasso, V. Ya. (1999). Monitoringovye issledovaniya fauny presmykayushihsya Dneprovsko-Orelskogo prirodnogo zapovednika [Monitoring studies of fauna of reptiles of the Dnieper-Orel nature reserve]. Biologicheskie issledovaniya na prirodoohrannyh territoriyah i biologicheskih statsionarah. Tez. dokl. Yubilejn. konf., posvyasch. 85-letiyu biol. stantsyi Khark. gos. un-ta. Kharkov, 43-44 (in Russian).

Gasso, V. Ya., Suhanova, V. N. (1993). Presmykayuschiesya Dneprovsko-Orelskogo zapovednika i ih ispolzovanie v sisteme ekologicheskogo monitoringa [Reptiles of the Dneprovsko-Orelsky Nature Reserve and their use in the environmental monitoring system]. Ekologichni osnovy optimizaciyi rezhimu ohorony i vykorystannya pryrodnozapovidnogo fondu. Rahiv, 243-244 (in Russian).

Gibbons, J. W., Scott, D. E., Ryan, T. J., Buhlmann, K. A., Tuberville, T. D., Metts, B. S., Greene, J. L., Mills, T., Leiden, Y., Poppy, S. (2000). The global declines of reptiles, Deja vu amphibians. BioScience, 50, 653-666.

Kotenko, T. I., Shaitan, S. V., Starkov, V. G., Zinenko, O. I. (2011). The northern range limit of the dice snake (Natrix tessellata) in Ukraine and the Don river Basin in Russia. Mertensiella, 18, 311-325.

Khobot, V. V., Novitsky, R. O., Bondarev, D. L. (2014). Konkurentsiya predstavnykiv rodyny Bychkovi (Gobiidae) z inshymy vydamy ryb vodojm Prydniprov'ya [Competitive relationship between members of the Gobiidae family and other fish species of waters of Pridneprovye region]. Vìsnik Dnìpropetrovs'kogo unìversitetu. Seriâ Bìologîa, ekologiâ, 22(2), 110-114 (in Ukrainian).

Kurtyak, F. F., Bilinec', I. V., Mokrani, A. V. (2012). Demekologichni osoblyvosti Natrix tessellata (Laurenti, 1768) na terenah pivdenno-zahidnogo makroshylu Ukrainskyh Karpat [Distribution and Quantity of Populations of Natrix tessellata (Laurenti, 1768) of the Transcarpathian Region (Ukraine)]. Naukovyj visnyk Uzhgorodskogo universytetu Seriya Biologiya, 33, 127-132 (in Ukrainian).

Lawing, A. M., Polly, P. D. (2011). Pleistocene climate, phylogeny, and climate envelope models: An integrative approach to better understand species' response to climate change. PLoS ONE, 6 (12), e28554.

Misyura, A. N. (1981). Ekologo-biohimicheskie pokazateli ozernoj lyagushki $\mathrm{v}$ usloviyah promyshlennogo zagryazneniya vodnyh ekosistem [Ecological and biochemical indices of the marsh frog under conditions of industrial pollution of aquatic ecosystems]. Voprosy herpetologii. Nauka, Leningrad, 89 (in Russian).

Misyura, A. N. (1984). Nekotorye voprosy ekotoksikologii beshvostyh amfibij $\mathrm{i}$ reptilij $\mathrm{v}$ tehnogennyh rajonah [Some issues of ecotoxicology of tailless amphibians and reptiles in technogenic areas]. Voprosy herpetologii. Nauka, Leningrad, 112 (in Russian).

Misyura, A. M., Nozdrachiov, V. V., Poloz, O. V., Gasso, V. Ya. (1992). Rol' Dniprovsko-Orilskogo zapovidnyka u zbilshenni 
kilkosti ridkisnyh ta znykayuchih vydiv herpetofauny Prydniprov'ya [Role of the Dniprovsko-Orilsky Nature Reserve in the increase of number of rare and endangered herpetofauna species of the Prydniprov'ya]. Problemy ohorony vydiv fauny i flory zanesenyh do Chervonoi knygy Ukrainy. Mikolayiv, 103-104 (in Ukrainian).

Moreno-Rueda, G., Pleguezuelos, J. M., Pizarro, M., Montori, A. (2011). Northward shifts of the distribution of Spanish reptiles in association with climate change. Conservation Biology, 26, 278-283.

Nekrasova, O. D., Gavris, G. G., Kuybida, V. V. (2013). Changes in the Nothern Border of the Home Range of the Dice Snake, Natrix tessellata (Reptilia, Colu-bridae), in the Dnipro Basin (Ukraine). Vestnik zoologii, 47(5), 475-479.

Nekrasova, O. D., Tytar, V. M. (2014). Modelirovanie i bioklimaticheskij analiz izmenenij areala uzha vodyanogo Natrix tessellata (Reptilia, Colubridae) v Ukraine [Bioclimatic modeling and analysis of home range changes in the dice snake Natrix tessellata (Reptilia, Colubridae) in Ukraine]. Pratsi ukrainskogo herpetologichnogo tovarystva, 5, 80-83 (in Russian).

Olson, D. H., Saenz, D. (2013). Climate Change and Reptiles. U.S. Department of Agriculture, Forest Service, Climate Change Resource Center. www.fs.usda.gov/ccrc/topics/wildlife/reptiles/.

Pakhomov, O. Ye., Gasso, V. Ya., Goloborodko, K. K., Poliakov, M. V., Grytsan, Yu. I., Bulakhov, V. L., Brygadyrenko, V. V., Klyuchko, Z. F., Mezhzherin, S. V., Novitsky, R. O., Pysanets, Ye. M., Plyushch, I. G., Ponomarenko, O. L., Puchkov, O. V., Radchenko, V. G. (2011). Chervona knyga Dnipropetrovskoi oblasti. Tvarynnyj svit. Novyj Druk, Dnipropetrovsk (in Ukrainian).

Refsnider, J. M. (2012). Effects of climate change on reptiles with temperature-dependent sex determination and potential adaptation via maternal nest-site choice. Graduate Theses and Dissertations. 12570. Iowa State University, Ames, Iowa. https://lib.dr.iastate.edu/etd/12570

Shurda, K. E. (2014). Realii Ukrainy v protsesse sovremennogo izmeneniya klimata. [Realities of Ukraine in the process of modern climate change]. Visnyk Odeskogo derzhavnogo ekologichnogo universytetu, 18, 56-64 (in Russian).

Sinervo, B., Méndez-de-la-Cruz, F., Miles, D. B., Heulin, B., Bastiaans, E., Cruz, M. V.-S., Lara-Resendiz, R., MartínezMéndez, N., Calderón-Espinosa, M. L., Meza-Lázaro, R. N., Gadsden, H., Avila, L., Morando, M., De la Riva, I. J., Sepulveda, P. V., Rocha, C. F. D., Ibargüengoytía, N., Puntriano C. A., Massot, M., Lepetz, V., Oksanen, T. A., Chapple, D. G., Bauer, A. M., Branch, W. R., Clobert, J., Sites Jr., J. W. (2010). Erosion of lizard diversity by climate change and altered thermal niches. Science, 328, 894-899.

Smirnov, N. A., Skilsky, I. V. (2017). Poshyrennya zvychajnogo (Natrix natrix) i vodyanogo (N. tessellata) vuzhiv (Reptilia: Colubridae) u Cherniveckij oblasti [Distribution of grass (Natrix natrix) and dice (N. tessellata) snakes (Reptilia: Colubridae) in Chernivtsi region]. Regionalni aspekty florystychnyh i faunistychnyh doslidzhen: materialy IV mizhnar. nauk.-prakt. konf. Ed. I. V. Skilsky, A. V. Yuzyk. Druk Art, Chernivtsi, 19-25 (in Ukrainian).

The Reptile Database. Release: 02 July 2018. http://reptiledatabase.reptarium.cz/.

Weatherhead, P. J., Sperry, J. H., Carfagno, G. L. F., Blouin-Demers, G. (2012). Latitudinal variation in thermal ecology of North American ratsnakes and its implications for the effect of climate warming on snakes. Journal of Thermal Biology, 37, 273-281.

Zani, P.A., Rollyson, M. (2011). The effects of climate modes on growing-season length and timing of reproduction in the Pacific Northwest as revealed by biophysical modeling of lizards. The American Midland Naturalist, 165, 372-388.

Zinenko, O., Korshunov, O., Tupikov, A. (2014). Amfibii i reptilii natsionalnogo prirodnogo parka «Dvurechanskij» [Amphibia and Reptilia of the National Nature Park "Dvorichanskyi"]. Visnyk Kharkivskogo natsionalnogo universytetu imeni V.N.Karazina. Seriya: biologiya, 19(1097), 68-74 (in Russian). 